DOI: $10.2478 / \mathrm{v} 10025-012-0004-1$

JOURNAL OF WATER

AND LAND DEVELOPMENT

J. Water Land Dev. No. 15, 2011: 41-51

\title{
Permanent turf grass as the factor alleviating water erosion in the Carpathian Mountains
}

\author{
Agnieszka KOWALCZYK, Stanisław TWARDY, Antoni KUŹNIAR
}

Institute of Technology and Life Sciences at Falenty, Małopolska Research Centre in Kraków, ul. Ułanów 21B, 31-450 Kraków, Poland, phone/fax +48 12 412-84-59, e-mail: itepkrak@itep.edu.pl

\begin{abstract}
Soil erosion by water is an important economical issue, because it strongly degrades the environment. This phenomenon occurs in the Carpathian mountain areas, and it is caused largely by inappropriate land use. And in the last quarter of the century, in whole region significant structural changes took place - an increase of grassland areas. Research was made in the period of 2008-2010 in the Biała Woda catchment area $\left(10.91 \mathrm{~km}^{2}\right)$ - the Carpathian Mts. The study area under discussion is characterised by low share of arable lands and by high contribution of the permanent grasslands. In this paper the mass of eroded materials was determined by applying of the universal soil losses equation - USLE (WISCHEIER and SMITH, 1978), using main factors, which have the impact on shaping the catchment area e.g. geological structure, terrain relief, the soil, climate, particularly precipitation, land use and slopes. Main attention was focused on agricultural land use (grasslands), hydrographical and road network. Sometimes the field roads becomes streams (gullies, which create favourable conditions for linear erosion e.g. for transporting eroded material during, heavy rainfall. Therefore, structural-spatial changes which now are taking place sometimes intensify the erosion process.
\end{abstract}

Key words: erosion, grassland, soil losses equation, turf

\section{INTRODUCTION}

The mountain regions are characterised by the high totals of precipitation as well as by considerable inclination of the hillsides (DYNOWSKA and MACIEJEWSKI, 1991). From these regards, they are particularly threatened by erosion process, particularly by water erosion. Principal elements which decided about the magnitude of erosion are: geological structure, the soil, climate (particularly precipitation), land use, relief and land slopes. Agricultural land use in this of plough method of cultivation favours water erosion, mainly surface. In turn, dense hydrographical network and the road net, in the period of tempestuous rains is transforming into streams, which accelerate, drainage of the eroded materials from the field surfaces (PROCHAL et al., 2000). The water erosion of the soil is an important economical 
problem, because it strongly degraded the natural environment. This phenomenon occurs on about $60 \%$ of the area of the Polish Carpathians, and it is caused, in considerable degree, by unsuitable land use as well as inappropriate distribution pattern of the arable lands. In the last quarter of the century significant structural changes took place, an increase of grasslands; hence they gather peculiar production and protective significance (GERLACH, 1966; JAGLA, 1965; TWARDY, 1993; WOCH, 2008). At present, determination of the amount of soil losses gains significance, because the management conditions in the mountain areas are changing as well as a share of permanent turf-forest cover has increased (SZEWRAŃSKI et al., 2008). This is contributed by the Development Plan of the Rural Areas (PROW), which has been implemented in Poland since 2004, and it aims towards an improvement of the quality of the environment and limiting water erosion through financial help to farmers. The aim of research was to determine the mass of soil losses in the mountain areas, in the 2010 water year, as an example of the Biała Woda catchment. This year is characterised by very high precipitation amounts which were higher of $55.7 \%$ as compared to long term averages.

\section{THE STUDY AREA}

Research was conducted in the Biała Woda catchment (Fig. 1). This catchment, together with tributaries constitutes the basin of upper section of the Grajcarek River, which lies in the middle part of the Pieniny Rock Belt. The Biała Woda catchment occupies the area of $10.91 \mathrm{~km}^{2}$; relief of the terrain is greatly diverse - the difference between the lowest point of the catchment (Jaworki $570 \mathrm{~m}$ a.s.1.) and the highest point (Rohacze foot $1060 \mathrm{~m}$ a.s.1.) is $490 \mathrm{~m}$ a.s.1. The Biała Woda stream has five larger tributaries, which cut the catchment up to the borders of watershed (TWARDY, 1993).

The soil cover in the Biała Woda catchment is typologically diverse depending on the type of the rock stratum, however, its thickness and several physicalchemical features in a larger degree are conditioned by the erosion-denudation process as well as by human agricultural activities. The deepest soil profiles were formed within flat hilltops, agricultural terraces, at foot of hillsides and in the bottom of the valleys, meanwhile the shallowest profiles are on the steep mountainsides in surroundings of the rock forms. The majority of the soils are characterised by fairly well developed profiles, and only locally their cover has initial character. In the area under discussion several soil types occur (Fig. 2).

The brown soils are most widely spread, which occupy about $85 \%$ of the catchment area. These soils in the upper parts of the terrain are acidified with a grain-size composition of loamy sands and light loams (acid brown), and at lower parts with a smaller acidity, as medium loams and heavy loams (characteristic brown). The podzolic soils occupy $1.5 \%$ of the area were formed on noncarbonated 


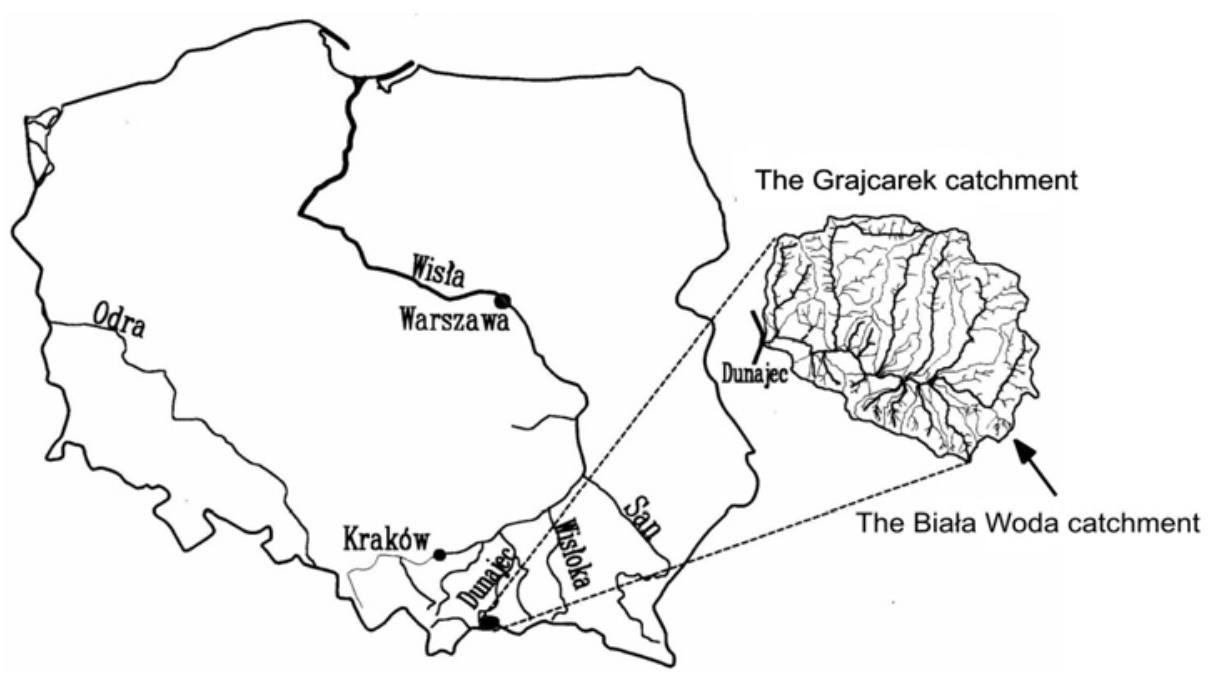

Fig. 1. The study area

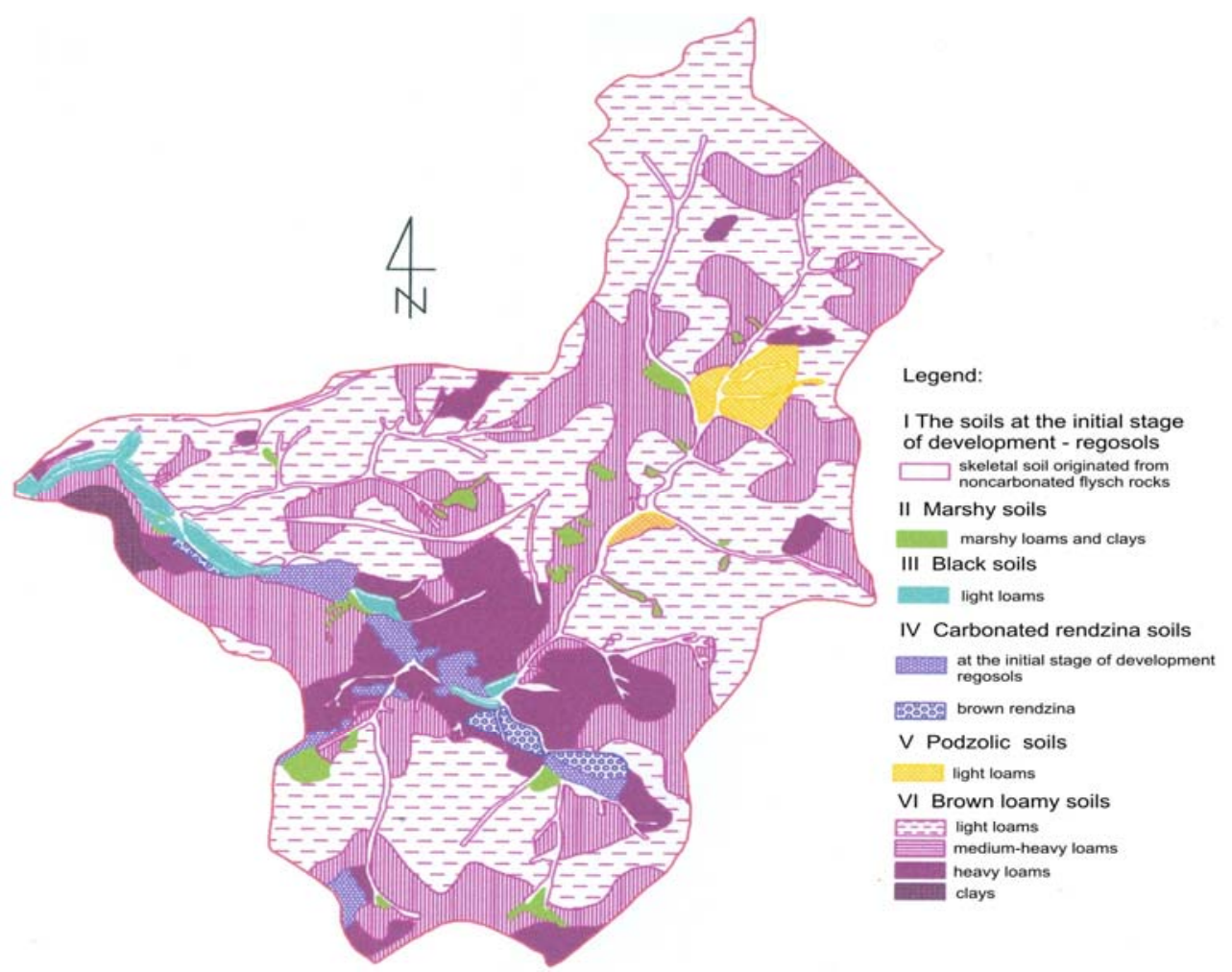

Fig. 2. The soils of the Biała Woda catchment (based on the data from DoBRZAŃSKI et al. (1958)) 
rock mantle of flysch complex. The rendzina soils occur here and there on carbonated stratum and they have not infrequently initial character. The black soils which usually are characterised by a deep humus stratum, they are lining the bottoms of a larger valleys, covering fluvial terraces. Marshy soils are filling different places among brown loamy soils, medium, heavy clayish. The soils at the initial stage of profile development constitute about $8 \%$ of the area. They are occurring in the form of skeletal deposits from noncarbonated flysh rocks and to this group belong: debris and rocky soils (DoBRZAŃSKI et al., 1958). Land use in the Biała Woda catchment is shown in Fig. 3 and in Tab. 1.

The catchment under consideration is characterised by a small share of arable lands $(0.8 \%)$ and substantial contribution of grasslands $-40.0 \%$ of area.

Meteorological measurements were made at the weather station at Jaworki (ITP). Registration included (among others parameters) monthly precipitations (Fig. 4).

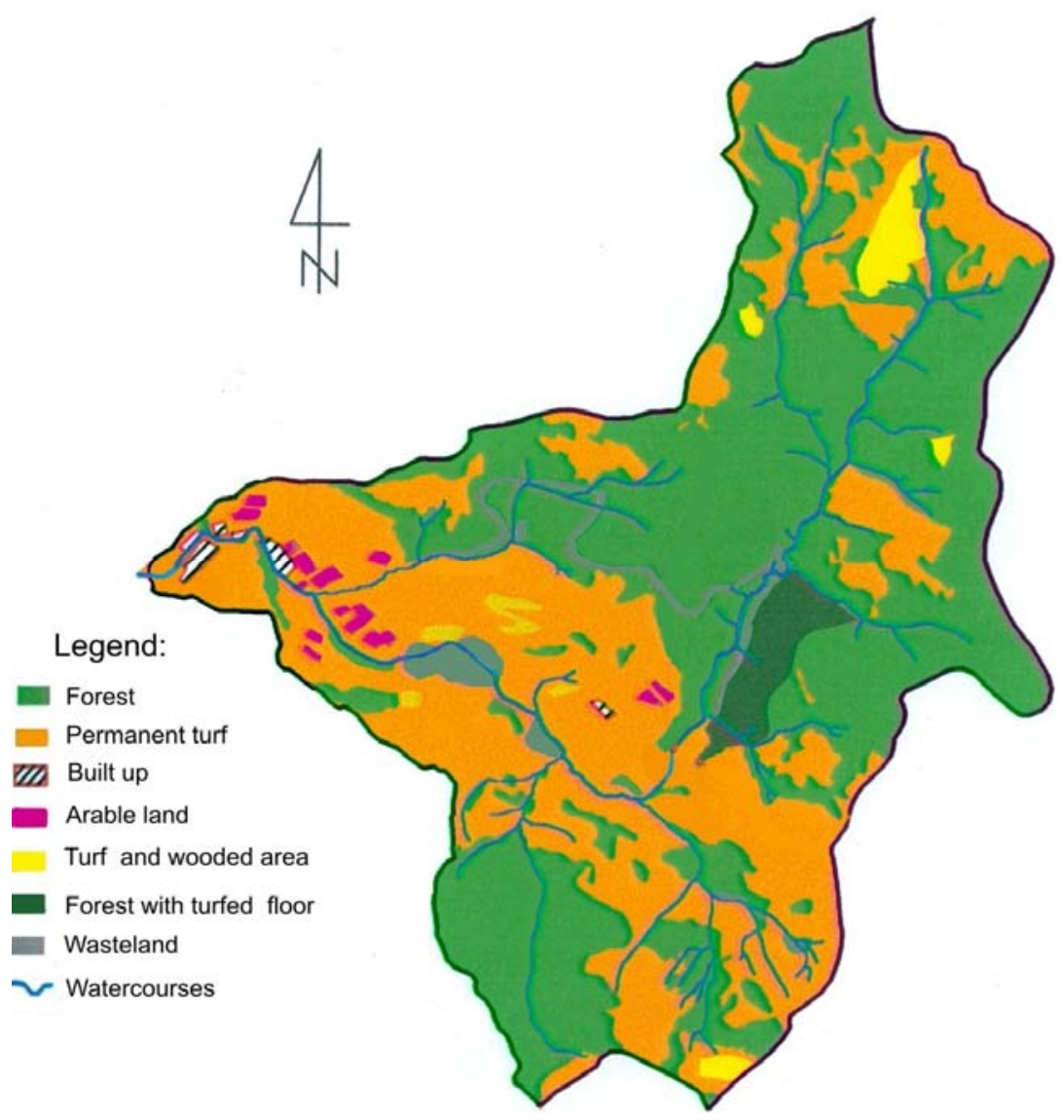

Fig. 3. Land use in the Biała Woda catchment area (from an original map by KoPACZ (2003)) 
Table 1. Land use in the Biała Woda catchment

\begin{tabular}{|c|c|c|c|c|c|c|}
\hline \multirow[b]{2}{*}{ Catchment } & \multirow{2}{*}{$\begin{array}{c}\text { Catchment area } \\
\mathrm{km}^{2}\end{array}$} & \multicolumn{5}{|c|}{ Land use, $\%$} \\
\hline & & forest & $\begin{array}{c}\text { turf } \\
\text { area-grass }\end{array}$ & arable lands & built up & $\begin{array}{l}\text { other and } \\
\text { wasteland }\end{array}$ \\
\hline Grajcarek & 84.4 & 68.0 & 27.9 & 0.8 & 2.5 & 0.8 \\
\hline Biała Woda & 10.9 & 56.2 & 40.0 & 0.7 & 0.5 & 2.6 \\
\hline
\end{tabular}

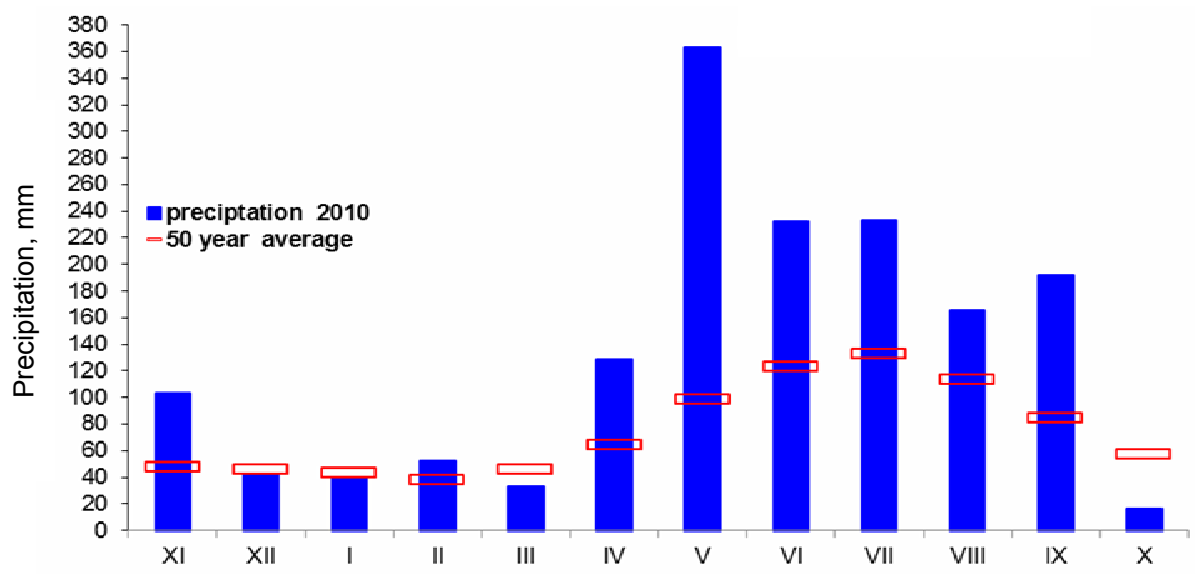

Fig. 4. Monthly precipitation in the 2010 water year as compared to 50 year averages

In the 2010 water year, the total annual amount of precipitation was very large and almost twice exceeded long term mean from the period 1970-2010, reaching $1602.0 \mathrm{~mm}$. The heaviest rainfall occurred in May, 2010 (362.6 mm), exceeding almost four times multiyear average. Abundant precipitations occurred also in January, June, July, August and September and were nearly twice higher than multiyear averages. Mean annual air temperature was $0.1{ }^{\circ} \mathrm{C}$ higher as compared to long term averages (Obserwacje..., 2010).

\section{MATERIAL AND METHODS}

In order to define water erosion process it is necessary to determine the quantity of surface runoff and the soil material carried after each rainfall. Estimation of the displaced soil within the catchment area was made by using USLE model Universal Soil Loss Equation - Program DR-USLE (BANASIK and GÓRSKI, 1991). The method is based on an analogy between amount of erosion which occurs in standard plot of length of $22.1 \mathrm{~m}$, located on a slope with gradient of $9 \%$, to the amount of soil loss in the given area under consideration (BANASIK et al., 1995; 
BANASIK and GÓRSKI, 1992; NEARING et al., 1989). For soil erosion analysis the model elaborated by Wischeier and Smith was applied. It shows average soil losses, whereas applied parameters in universal soil loss equation are mean values for separated catchments and areas (STONE and HILBORN, 2000; WISCHEIER and SMITH, 1978).

Universal soil loss equation has the following form:

$$
A=R K L S C P
$$

where:

$A$ - represents the potential long term average annual soil loss, $\mathrm{t} \cdot \mathrm{km}^{-2} \cdot \mathrm{y}^{-1}$.

The respective elements of the above equation are described below.

Coefficient $\boldsymbol{R}$ - mean annual erosive factor of rainfall and runoff (expressed in $\mathrm{Je}^{-1} \mathrm{y}^{-1} ; \mathrm{Je}-$ so called unit of rainfall erosivity): can be estimated from formula:

$$
R=R r+R s
$$

where:

$R r$ - erosive factor of rainfall and in a result the surface runoff, $\mathrm{Je}^{-} \mathrm{y}^{-1}$;

$R s$ - erosive factor of thaw runoff, $\mathrm{Je} \cdot \mathrm{y}^{-1}$.

Parameter $R$ is determined on the base of long term precipitation data. The mean annual erosive factor of precipitation is estimated with distribution through the year (BANASIK et al., 2001; BANASIK and GÓRSKI, 1993).

Coefficient $\boldsymbol{K}$ - susceptibility of the soil to erosion, which depends on granulation composition. The value of $K$ coefficient can be estimated from appropriate diagram modified by Schwertmana (BANASIK and GÓRSKI, 1992) or by applying the equation as below:

$$
K=2.77 \cdot 10^{-6} M^{1.14}(12-O S)+0.043(A-2)+0.033(D-3)
$$

where:

$M$ - product of the grain percentage contents: $0.002-0.1 \mathrm{~mm}$ and grains $0.002-2.0 \mathrm{~mm}$;

$O S$ - content of the humus substances, \% (when $O S>4.0 \%$, it is assumed equal $4.0 \%$;

A - class texture of the soil,

$D$ - permeability class of the soil.

Coefficient $\boldsymbol{L}$ - characterises the features of hillside slope and it is the ratio of eroded soil from the plot of considered length to the amount of eroded soil from the standard plot, when the remaining conditions, which have the impact on an intensity of this process, are identical. Its value can be estimated from equation (4). 
Coefficient $\boldsymbol{S}$ - it is characteristic of the hillside slope, being the ratio of eroded soil from the plot at given gradient to the amount of soil loss from standard plot with steepness of $9 \%$, when remaining conditions which influence the intensity of the process are identical.

$$
L S=\left(\frac{\lambda}{22.1}\right)^{m}\left(0.065+0.0454 s+0.0065 s^{2}\right)
$$

where:

$$
\begin{aligned}
& \lambda=0.5 \frac{D A}{L s} \quad-\text { length of hillside-side equal to the way of the surface flow, } \mathrm{m} \text {; } \\
& \text { DA - catchment area, } \mathrm{m}^{2} \text {; } \\
& \text { Ls } \quad-\text { length of all water streams in the catchment area, m; } \\
& s \quad-\text { slope of the hillside, \%; } \\
& m \quad-\text { index of power depending on the slope of hillside (STONE and } \\
& \text { HILBORN, 2000): } \\
& m=0.2 \text {, when } \mathrm{s} \leq 1.0 \% \text {; } \\
& m=0.3 \text {, when } 1.0<s<3.0 \% \text {; } \\
& m=0.4 \text {, when } 3.0 \leq s<5.0 \% \text {; } \\
& m=0.5 \text {, when } \mathrm{s} \geq 5.0 \% \text {. }
\end{aligned}
$$

Coefficient $\boldsymbol{C}$ - ratio of the soil losses from a given hillside land, under a specific crop and management system to the corresponding loss from an identical fallow and tilled land along slope. Protective function of vegetation against erosion changes together with the phenological stages of the plant growth. During sowing or shortly after, the amount of the eroded soil is considerable higher than during full growing season.

Coefficient $\boldsymbol{P}$ - ratio of the soil losses from the slope when the most common practices are used to limit erosion (e.g. cross slope cultivation, contour farming and strip-cropping) to the losses from an identical hillside with farming up and down the slope (Tab. 2).

Table 2. The coefficients P for the different methods of land cultivation (STONE and HiLBORN, 2000)

\begin{tabular}{l|c}
\hline \multicolumn{1}{c|}{ The method of cultivation } & Coefficient $P$ \\
\hline Up and down slope & 1.00 \\
Cross slope & 0.75 \\
Terracing & 0.50 \\
Strip-cropping & 0.37 \\
Contour & 0.25 \\
\hline
\end{tabular}


In order to estimate the mass of eroded soil from the unit area, "Universal Soil Loss Equation" (USLE)" was used. Depending on the amounts of soil losses from the unit area the degree of erosion can determine based on the classification shown in Tab. 3 (below).

Table 3. Classification of water erosion (ZACHAR, 1982)

\begin{tabular}{ccc}
\hline The degree of erosion & Erosion description & Amount of soil losses, $\mathrm{t} \cdot \mathrm{km}^{-2} \cdot \mathrm{y}^{-1}$ \\
\hline I & negligible & $<25$ \\
II & weak & $25-250$ \\
III & moderate & $250-700$ \\
IV & average & $700-2500$ \\
V & intense & $2500-10000$ \\
VI & catastrophic & $>10000$ \\
\hline
\end{tabular}

\section{RESULTS AND DISCUSSION}

The analysis and calculations made by applying Universal Soil Loss EquationUSLE (WISCHEIER and SMITH, 1978) allowed for estimation of the eroded mass from the unit area of the Biała Woda catchment which has a large share of permanent grasslands and forest. Some spatial element which were used for calculations are shown in Tab. 4.

Table 4. Soil losses against a background of the Biała Woda catchment characteristics

\begin{tabular}{|c|c|c|}
\hline \multicolumn{2}{|l|}{ Specification } & Values \\
\hline \multicolumn{2}{|l|}{ Area, $\mathrm{km}^{2}$} & 10.91 \\
\hline \multicolumn{2}{|c|}{ Average gradient of the catchment, $\%$} & 4.43 \\
\hline \multicolumn{2}{|c|}{ Density of stream network, $\mathrm{km} \cdot \mathrm{km}^{-2}$} & 3.15 \\
\hline \multicolumn{2}{|c|}{ Length of the stream, $\mathrm{km}$} & 7.93 \\
\hline \multicolumn{2}{|c|}{ Precipitation - 2010, mm } & 1602 \\
\hline \multirow{5}{*}{ Coefficients } & $\mathrm{R}, \mathrm{Je}$ & 193.8 \\
\hline & $\mathrm{K}, \mathrm{t} \cdot \mathrm{Je}^{-1} \cdot \mathrm{ha}^{-1}$ & 0.38 \\
\hline & L S & 2.29 \\
\hline & $\mathrm{C}$ & 0.01 \\
\hline & $\mathrm{P}$ & 0.49 \\
\hline \multicolumn{2}{|c|}{ Soil losses, $\mathrm{t} \cdot \mathrm{km}^{-2} \cdot \mathrm{y}^{-1}$} & 87.4 \\
\hline
\end{tabular}

Applying Zachar's classification (ZACHAR, 1982), the result grades the terrain to the II degree, described as weak. The studies confirmed that land use method had principal impact on occurrence and the intensity of water erosion. Similarly 
research in the Sudety Mts. showed that permanent grasslands are in the lowest degree subjected to erosion (FATYGA, 1978).

The results obtained for the 2009/2010 water year showed that soil losses from the areas with permanent turf grass and forest were considerable higher than from studies of other authors (JAGLA, 1965; PROCHAL et al., 2000). One of the most probable reasons of occurrence of this phenomenon was very high precipitation, which particularly in the growing season, exceeded of about $100 \%$ long term averages. Such high precipitation amounts and sometimes their accumulation caused intensive phenomenon of water erosion, which was encountered in the years with average precipitation.

\section{REFERENCES}

BANASIK K., GóRSKI D., 1991. Dokumentacja programu DR - USLE v 2.0. (Documentation of DR USLE v 2.0). Warszawa, SGGW: 1-53.

BANASIK K., GÓRSKI D., 1992. Wykorzystanie uniwersalnego równania strat glebowych USLE do oceny ilości rumowiska unoszonego odpływającego z małych zlewni. (The use of the Universal Soil Loss Equation USLE for assessment of quantity of floating rubble flowing from small catchments). Gospodarka Wodna, 3: 62-65, 67.

BANASIK K., GÓRSKI D., 1993. Evaluation of rainfall erosivity for east Poland. In: Runoff and sediment yield modeling. Eds K. Banasik, A. Żbikowski. Proceedings of Internationale Symposium. Warszawa, Wydaw. SGGW: 129-143.

BANASIK K., GóRSKi D., Mitchell J.K., 2001. Rainfall erosivity for east and central Poland. In: Soil Erosion Research of the 21st Century. Proceedings of the Internationale Symposium. Honolulu, Hawai, ASAE: 279-282.

BANASIK K., GÓRSKi D., SKIBIŃSKi J., 1995. Metodyka oceny intensywności erozji powierzchniowej i akumulacji rumowiska w zbiornikach wodnych. W: Metodyka zagospodarowania zasobów wodnych w małych zlewniach rzecznych. (Methodology of the assessment of surface erosion intensity and rubble accumulation in water basins. In: Methodology of the management of water resources in small river catchments). Ed. A. Ciepielowski. Warszawa, Wydaw. SGGW.

Dobrzański B., Gliński J., GuZ T., Pomian J., 1958. Gleby terenu dorzecza Białej Wody. (Soils of the area of Biała Woda basin). Roczniki Nauk Rolniczych, 72-F-3: 963-990.

DynOwSKa, MacieJEWSKi M. (Eds). 1991. Dorzecze górnej Wisły. (The catchment of the Upper Vistula River). Warszawa-Kraków, PWN: 1-341.

FATYGA J., 1978. Procesy erozyjne na górskich użytkach zielonych. (Erosive processes in mountain grasslands). Wiadomości IMUZ, 12, 4: 253-270.

GERLACH T., 1966. Współczesny rozwój stoków w dorzeczu górnego Grajcarka (Beskid Wysoki Karpaty Zachodnie) (Recent development of slopes in upper Grajcarek River basin (Beskid Wysoki - Western Carpathians)). Prace Geograficzne IG PAN, 52: 1-111.

JAGŁA S., 1965. Wstępne badania nad wielkością zmywu gleb w terenach podgórskich przy różnym ich pokryciu. (Initial researches on the rate of soil runoff in piedmont terrains with various coverage). Wiadomości IMUZ, 6, 3: 115-123.

KoPACZ M., 2003. Wody powierzchniowe potoków Karpackich w warunkach zmian strukturalnośrodowiskowych. (Surface waters of Carpathian streams in response to structural-environmental transformations). Falenty, Wydaw. IMUZ: 1-88 
Nearing M.A., Foster G. R., LAne L.J., Finkner S.C., 1989. A process - based soil erosion model for USDA - Water Erosion Prediction Project Technology. Transactions of the ASAE, 32, 5: $1587-1593$.

Obserwacje meteorologiczne w Stacji Badawczej Jaworki, Małe Pieniny, 2010. (Meteorological observations at measuring station for Jaworki, Małe Pieniny). Sprawozdanie z problemu. Kraków, Małopolski Ośrodek Badawczy ITP.

Prochal P., MaŚlanKa K., Koreleski K., 2000. Ochrona środowiska przed erozją wodną. (Protection of environment from the water erosion). Kraków, Wydaw. AR: 1-126.

Starkel L., Baumgart-Kotarba M., Michna E., Gil E., Pohl J., SŁupik J., Zawora T., 1978. Studia nad typologią i oceną środowiska geograficznego Karpat i Kotliny Sandomierskiej. (Studies in the typology and geographic environment evaluation of the Carpathians and the Sandomierz Basin). Prace Geograficzne IG PAN, 125: 1-165.

Stone R. P., Hilborn D., 2000. Universal soil loss equation (USLE). Ontario, Min. Agricult. Food Rural Affairs: 1-9.

SZEWRAŃSKI SZ., SASIK J., WAWER R., ŻMUDA R., 2008. Propozycje rolnośrodowiskowego zagospodarowania przestrzennego zlewni w aspekcie ochrony gruntów rolnych przed erozją wodna. (The proposal of agri-environmental spatial management of water erosion control in agricultural lands). Przegląd Naukowy Inżynieria i Kształtowanie Środowiska, 2 (40): 34-42.

TWARDY S., 1993. Warunki przyrodnicze a użytkowanie ziemi w Karpatach. (Carpathian agricultural land as less favoured areas (LFA). Postępy Nauk Rolniczych, 3: 51-60.

WischeIER W.H., SMITH D.D., 1978. Predicting rainfall erosion losses - a guide to conservation planning. U.S. Dep. Agricult. Handb.: 1-537.

Woch F., 2008. Analiza metod przeciwerozyjnej ochrony gleb stosowanych w procesie urządzeniowym. (The analyze of methods of antierosion soil protection in land management process). Przegląd Naukowy Inżynieria i Kształtowanie Środowiska, 2 (40): 12-24.

ZACHAR D., 1982. Soil erosion (Developments in soil science). Elsevier Science Ltd: 1-548.

\section{STRESZCZENIE}

\section{Trwałe zadarnienie gleb jako czynnik łagodzący procesy erozji wodnej w obszarach karpackich}

Słowa kluczowe: erozja glebowa, równanie strat glebowych USLE, zlewnia górska

Erozja wodna gleb jest ważnym problemem gospodarczym, gdyż silnie degraduje środowisko przyrodnicze. Zjawisko to występuje na ok. $60 \%$ powierzchni obszarów górskich Karpat i jest w znacznej mierze spowodowane nieodpowiednim użytkowaniem ziemi, jak również nieprawidłowym rozmieszczeniem gruntów ornych. W ostatnim ćwierćwieczu nastapiły istotne zmiany strukturalne - zwiększenie udziału użytków zielonych, dzięki czemu nabierają on szczególnego znaczenia produkcyjno-ochronnego.

W pracy określono masę erodowanego materiału glebowego z zastosowaniem równania strat glebowych - USLE, opracowanego przez Wischeiera i Smitha. Wykorzystano główne czynniki wpływające na kształtowanie powierzchni zlewni, tj.: budowę geologiczna, rzeźbę terenu, glebę, klimat, zwłaszcza opady atmosferyczne, użytkowanie i spadek. Szczegółowo omówiono użytkowanie rolnicze ziemi, sieć 
hydrograficzną oraz sieć drogową. Drogi polne stają się tu niekiedy potokami, co sprzyja erozji liniowej, tj. odprowadzaniu w czasie dużych opadów erodowanego materiału. Dlatego też zachodzące obecnie przeobrażenia strukturalno-przestrzenne niekiedy intensyfikują procesy erozyjne.

Zlewnia Grajcarka o powierzchni $84,45 \mathrm{~km}^{2}$, jest użytkowana w sposób istotnie zróżnicowany. Do szczegółowej analizy wybrano więc zlewnię Białej Wody. Dorzecze Białej Wody zajmuje powierzchnię 10,91 km², rzeźba terenu jest silnie zróżnicowana, różnica miedzy najniższym a najwyższym punktem dorzecza wynosi 490 m n.p.m. Potok Biała Woda ma pięć większych dopływów, które rozcinają dorzecze Białej Wody do granic wododziału. W rozpatrywanym roku hydrologicznym (2010) masa erodowanej gleby wynosiła $87,4 \mathrm{t} \cdot \mathrm{km}^{-2} \cdot \mathrm{r}^{-1}$. Wynik ten klasyfikuje teren do II stopnia erozji wg Zachara, czyli słabej. 